'If you'd had my life, you'd have done it too': exploring the experiences of adult males who rape elderly females

Rosanna Murphy ${ }^{1 *} \&$ Belinda Winder ${ }^{2}$

${ }^{1}$ Psychology, HMP Whatton, New Lane, Whatton, NG13 9FQ

${ }^{2}$ Sexual Offences Crime and Misconduct Research Unit, Division of Psychology, Nottingham Trent University, Nottingham, UK, tel 01158485535 


\section{Acknowledgements}

The authors would like to acknowledge the help, support and guidance of HMP Whatton, and in particular, the participants. 


\title{
'If you'd had my life, you'd have done it too': exploring the experiences of adult males who rape elderly females
}

\begin{abstract}
This study focused on adult males who have committed a sexual offence against elderly victims (aged 55 and over) in order to increase our understanding of this group of offenders. Semi-structured interviews were conducted with five such individuals. Interview data were analysed using Interpretative Phenomenological Analysis (IPA). Four main themes emerged: life's been really tough (where participants talked about difficulties they had faced); I'm not bad, I did what anyone would do (where participants sought to explain their behaviour); Other people haven't helped or have made things worse (where participants highlighted challenges they faced in relationships and the impact they felt this had); and Coping and pleasure (which highlights the use of sex and alcohol in their lives). Implications for the practice and treatment of individuals offending against elderly victims are discussed.
\end{abstract}

Keywords: rape; sexual offending; elderly; qualitative; IPA; victims 


\section{'If you'd had my life, you'd have done it too': exploring the experiences of adult males who rape elderly females}

\section{Introduction}

Extensive research has been conducted to develop an understanding of men who sexually offend against children (Gannon \& O'Connor, 2011; Ciardha, 2011; Mcphail, Hermann \& Nunes, 2013; Babchishin, Nunes \& Kessous, 2014; Sigre-Leirós, Carvalho, Nobre, 2015) and men who rape adult women (Gannon, Collie, Ward, \& Thakker, 2008; Groth \& Birnbaum, 2013; Langton \& Marshall, 2001; Jewkes, Sikweyiya, Morrell \& Dunkle, 2014). In comparison, there is limited research focusing on sexual offences against the elderly (Ball, 2005). Janssen (2014) estimated that approximately six relevant case studies have been published since 1900. This is concerning since it cannot be assumed that theories derived from existing research can be applied to individuals who offend against the elderly. Consequently, Ball (2005) highlighted the need for further research to underpin the development of theoretical models to understand better those who target elderly victims.

Sexual offending against the elderly is less frequent than with other age groups, with a purported prevalence rate of $2-7 \%$ of victim samples (Amir, 1971; Cartwright \& Moore, 1989; Fletcher, 1977; Hicks, 1977; Macdonald, 1971). In a five year study in the UK, Lea, Lanvers and Shaw (2003) reported that six percent of their sample ( $n=379$ rapes) involved a victim over 50 years of age. 
In respect of crime generally, Help the Aged (2006) report that older people are less likely than younger groups to suffer serious personal crime, mainly due to a typically more restricted lifestyle. However, Help the Aged statistics from police reports suggested that the elderly are vulnerable to a number of crimes, including distraction burglary and financial abuse (Manthorpe et al., 2007). Research has indicated over 350,000 incidences of such crimes annually (Help the Aged, 2006). Scharf, Phillipson, and Smith (2002) highlighted that 40 percent of older participants in their research had been a victim of crime during the last two years, with 28 percent victims of property crime, 21 percent victims of burglary, and 15 percent assaulted and/or robbed in the street.

Thus it appears that a few offences that focus on the vulnerability of the victim are more common against the elderly, yet the prevalence of sexual offending against this group is lower than might be expected. There are a number of possible explanations for this: many sexual assaults of elderly victims are unreported (Klaus 2000; Tyra, 1996), indicating that actual prevalence is likely to be higher. In the UK, self-report data from the British Crime Survey has previously been constrained to those aged between 16 and 59 (Walby \& Allen, 2004), whilst police crime statistics do not typically identify the age of victims. Furthermore, the majority of crimes are logged under what is considered to be the overriding offence, (for example, burglary or murder) and therefore, when offences of these types involve a sexual element, this may not be captured in published statistics.

This latter point is important given a comparatively high proportion of rapes against the elderly result in the victim's death (Greenfield, 1997). According to the US report 
Sex Offense and Offenders (Klaus 2000), one in seven sexual assault murder victims were aged 60 or older; only rape victims aged between thirteen and seventeen years old had a higher murder rate. Groth (1979) similarly reported a high degree of brutality in sexual offences against the elderly, with 60 percent of offenders using weapons and 60 percent of victims receiving a serious injury. Sexual offences against the elderly cause particular shock to the public, partly because of the vulnerability of the victim (we may consider this as the offender-victim inequality gap), but also conceivably because the elderly are not synonymous with sexuality, which is rather the domain of the young (Twig, 2004). Yet research to date has identified commonalities of sexual offences against elderly victims, and also features that differentiate them from sexual offences against other age groups.

One explanation of the motivation behind sexual offending against the elderly is simply that the offending is sexually motivated, and the perpetrator is gerontophilic (Janssen, 2014), that is, they have a specific sexual interest in elderly people. This has been identified as an explanation in some individual case reports, such as Groth (1978). Gerontophilia has often been taken to denote a "paraphilic" interest in the elderly and in forensic contexts might be fitted into the diagnostic slots of DSM-5 "Other Specified" or "Unspecified Paraphilic Disorder" (American Psychiatric Association, 2013, p. 705). However, there is no evidence to indicate that a significant proportion of offenders who sexually assault elderly individuals are motivated by a specific sexual interest in this age group. In 2014, Janssen referred to the notion of gerontophilia as "little more than a nosological fossil” (p. 6). Groth (1978) identified 'anger rape' as an explanation for sexual offences against the elderly, suggesting that the offender directs feelings of anger towards the victim who is a substitute for the original source of anger; the rape 
is a means of causing hurt and humiliation rather than a primarily sexual act (Ball, 2005). Groth (1978) suggested the victim represents an authority figure who the offender wishes to hurt, control and degrade. Groth's model of offending was supported by Pollock (1988) who suggested that men who offended against elderly victims were likely to have been driven by rage and sadistic intent rather than sexual desire. In further support of this, Cartwright and Moore (1989) concluded from their retrospective analysis of reported sexual offences, that elderly rape is motivated by anger. Research has also suggested that availability and vulnerability are key factors in why sexual offenders may target elderly victims (Muram et al, 1992; Cartwright \& Moore, 1989).

Typologies and research into offenders' implicit theories (Ward, 2000) facilitate the formulation of models, providing avenues for research and evaluation. They can be useful in developing and directing appropriate treatment for offenders, focusing on the needs of that particular group. Specific offender typologies have been developed as a result of research into sexual abuse of children and adult women (Groth, 1979; Prentky \& Knight, 1991; Ward, 2000). Burgess et al. (2007) identified some support for the relevance of applying existing typologies to cases with elderly victims; however, no specific typologies have yet emerged.

Currently in UK Prisons, the Risk Need and Responsivity approach to offending behaviour underpins the approaches used in treatment (RNR; Andrews \& Bonta, 2007). This enables therapists to tailor treatment based on the offender's risk level, specific areas of criminogenic need and additional responsivity factors, such as level of intellectual functioning. In particular, the Structured Assessment of Risk and Need 
Treatment Need Analysis (SARN TNA; Thornton, 2002) is widely used in the UK to assist with the treatment of sex offenders. It is utilised to identify those offender characteristics, lifestyle factors and beliefs which are most strongly associated with sexual reconviction. Once treatment areas are identified for each individual, these areas can be targeted and addressed. Therefore, a clearer understanding of the specific treatment needs of men who sexually offend against elderly victims is required in order for the Risk Need and Responsivity approach to be effective with this group of offenders. While this can be identified in treatment on an individual basis, an improved understanding of men who sexually offend against elderly victims could determine whether there is a need for the current approach to treatment for sex offenders to be specifically tailored to their needs. Men who sexually offend against elderly victims are a small population within the overall population of sexual offenders. Therefore while they may have been included in the sample pool for research into the effectiveness of the SARN, specific needs may not be well represented in the data.

The current study aims to develop insight into the perspectives of adult males who have committed sexual offences against elderly female victims. This includes exploring beliefs that the offenders hold about their victims or older people in general. Interpretative Phenomenological Analysis (IPA) was used to aid the researchers in capturing the experiences and viewpoints of participants. IPA is deemed a suitable approach when the aim is to understand and explore how individuals perceive the situations they face and how they make sense of their personal and social world (Smith \& Osborn, 2007). In particular, IPA allows us an insight into excluded or hidden groups in society such as sexual offenders. It provides them with a voice to describe behaviours and experiences that are otherwise beyond the realm of most people's 
understanding (Winder \& Gough, 2010; Lievesley, Elliott, Winder, Norman \& Kaul, 2014; Waldram, 2007).

\section{Method}

\section{Sample}

The sample pool comprised twenty adult men currently in custody at a UK sex offender prison convicted of a sexual offence against an elderly victim. For the purpose of the study, victims were deemed to be elderly if they were aged 55 or over at the time of the offence. This age was chosen because it is the cut off age utilised by the UK prison service to denote a prisoner as 'elderly'. In addition to this, given that the average age of the menopause is aged 51 , it can be assumed that by the age of 55 the majority of women would be post-menopausal.

Level of responsibility taking was not utilised as an exclusion/inclusion criterion. However, none of the participants were in total denial of their offence, and all had completed at least one Offending Behaviour Programme (although it should be noted that the study was conducted in a treatment prison where there is a requirement for prisoners to be willing to address offending behaviour).

Of the twenty potential participants, six consented to participate in the study. One of these six was deemed unsuitable due to risk concerns. The remaining five participants constituted a modest but adequate number, sufficient for the purposes of Interpretative Phenomenological Analysis (IPA), the chosen methodology (Smith, 1995). Participants were aged between 20 and 46 years (Mean $=30.1$ ) at the time of 
offending and their victims were aged between 55 and 70 (Mean =63.0). Table 1 presents demographic and offence information on participants.

\section{INSERT TABLE 1}

\section{Interviews}

Access to participants was granted following ethical approval by Her Majesty's Prison Service and a UK University. Potential participants received a letter explaining the purpose of the research and detailing ethical procedures. Participants who expressed an interest in taking part were given further information about the research. All five interviews were conducted by the lead researcher, in a prison interview room. Participants were encouraged to 'tell their stories (Waldram, 2007) of how they 'ended up in prison' in their own words in the semi-structured interviews. The interview schedule encouraged participants to talk about what they believed were the main factors that lead to their offending, and was structured into a number of broad sections including upbringing, experience of relationships, employment, and relationship to the victim. As participants generally chose to tell their stories in a chronological way, the various sections were interlinked throughout the interview.

Interviews lasted between 1-3 hours (Mean: 1 hour 52 minutes). They were recorded on a dictaphone and transcribed using a primarily secretarial style transcription. However, some features of the Jefferson-style transcription (2004) were recorded, such as pauses and voice inflections. At times, the participants used language that may be considered offensive; such language was not removed and has been included 
in quotations within this paper. Name and places have been anonymised. Where names are used in the quotations, these are pseudonyms.

\section{Mode of Analysis}

Interpretative Phenomenological Analysis (IPA; Smith, 1995) was the chosen form of analysis. IPA assumes that the participant will reflect their underlying thoughts and feelings in their description of events, and views the participants as experts in the area being explored (Reid, Flowers \& Larkin, 2005). IPA also allows the researcher to interpret participant accounts to generate insights into the research area. It relies on the reflections and psychological interpretation of the researchers and acknowledges potential influence of the researchers in creating a theoretical understanding.

The analysis of the semi structured interview transcripts sought to understand how the participants made sense of their offences against elderly victims. Analysis followed the IPA guide outlined by Smith (2007). This involved reading, re-reading, note taking, developing initial clusters of themes for each transcript and grouping them together across the accounts. Once identified, primary themes and sub themes were then rearranged and linked back to the data multiple times to ensure that they were based on the participant insights and were not merely thematic. The second researcher read all transcripts, highlighting potential themes in the data, before going through the analysis created by the lead researcher. Several iterative stages of analysis and theming took place, with a constant re-checking and re-grounding back to the transcripts, before the final thematic structure was agreed by the researchers. This iterative process of cross-checking (between researchers) and re-checking (between emergent themes and transcript data) helps to underpin reliability in qualitative 
research, echoing the techniques of inter-rater reliability and test-retest reliability in quantitative research methods.

\section{Results}

\section{Overview of themes}

IPA analysis of the data highlighted four key themes: 1. Life's been really tough. 2. I'm not bad, I did what anyone would do. 3. Other people haven't helped me or have made things worse. 4. Coping and pleasure. The themes and associated sub-themes are considered in this section. An overview of the themes is provided in Table 2. (Individual participants will be referred to as $\mathrm{P} 1, \mathrm{P} 2$ etc.).

\section{INSERT TABLE 2}

\section{Superordinate theme 1: Life's been really tough}

The most prominent theme, echoed by all participants, was that they had suffered a tough start to life, and not been given a fair chance because of problems and difficulties in childhood, which continued and/or impacted upon their adult lives. This left participants with a view of a hostile world out there; as P1 affirms "The world is an oppressive place.". Participants portrayed dissatisfaction with their adult lifestyles, and a build-up of negative emotions (particularly anger) as a consequence, which ultimately resulted in their offending. Participants described situations that highlighted how their poor problem solving and interpersonal skills developed as result of their early life, leading to their offending.

Subordinate theme 1.1: I didn't get a good start in life (Childhood). 
The participants recounted a range of negative events/situations in childhood including sexual abuse, witnessing violence, racial abuse, neglect, instability, lack of intellectual ability and illness. While types of negative experiences varied, participants all suggested that were damaged by their childhood experiences. Two participants disclosed sexual abuse and P2 described how the trauma of sexual abuse affected his behaviour throughout his life, suggesting he was unable to manage the impact it had on him and that this ultimately is why he offended: "the nightmare that keeps coming back that, and which actually triggered the offence itself, was the first time she introduced me to oral sex."

Participants felt their experiences triggered negative emotions towards caregivers, feelings of helplessness and resentment towards those more fortunate than themselves. P2 talked about how his experiences of childhood abuse made it difficult for him to form satisfying relationships with women as an adult; other participants described poor attachments to their mothers and/or poor relationships with other women in their lives.

Childhood innocence was frequently highlighted by participants as something that was taken from them. For example, P4 described how he was abused and then sent to care where he was further abused. The negative events participants described were not exclusively abuse or neglect: P1 talked about how racist attacks impacted on his academic achievements:

"to kind of deal with the racism, and the generally, and just being in a rougher environment in general, I became rougher.... my grades at 
school were suffering, I was very bright at school initially as well, and that, and everything just suffered when we moved"

As the quote suggests, participants felt that things could have been different if it was not for their negative experiences in childhood. It is worth noting that not all participants drew explicit links between negative childhood events and who they became. However, all generally described themselves as confused children who initially trusted people, but lacked a consistent home environment, were mistreated or neglected, and received a lack of love and affection from caregivers. As a result, as adults, they experienced difficulties making friends, having healthy relationships and perspective taking.

The events described from participants' childhoods highlight their sense of innocence, vulnerability and lack of control over situations at the time; the latter in particular appears to have triggered an external locus of control. For example, P3 described himself as "backward" with "no prospects" and presented a passive and accepting attitude towards this. Participants focussed on the negative events that happened to them as children without demonstrating a critical attitude towards their thinking and behaviour; or the capacity to deal with ongoing negative effects of these experiences as adults.

\section{Subordinate theme 1.2: Bad things have happened to me (adulthood).}

Participants talked about extreme negative events that affected them and difficulties in early adulthood, including bereavement, employment and money problems, instability, depression and violence towards them. Participants described a sense of feeling further damaged by negative events in adulthood, reinforcing their precarious 
view of the world and other people. P3 recalled being in a car crash where his partner and his friend had died, claiming that this relationship would have been a stable, happy one, but it was lost. P4 also recounted a good friend's death, and other participants mentioned the death of family members. They demonstrated a common belief that, had these events not happened, life may have taken a more positive route.

The majority of participants described problems with employment, such as trouble getting work, not enjoying their work, or losing jobs (which they often saw as out of their control). P3 felt that he lost his job due to depression; he appeared to accept the suggestions of others that his depression was due to childhood experiences:

"...because l'd been through lots of different sorts of things through me life, they think it's from my childhood"

The negative experiences that participants described in adulthood were often perceived as later consequences of negative childhood experiences.

\section{Subordinate theme 1.3: My life's not what I wanted it to be.}

Many participants recalled feeling unsatisfied with their lives, describing unstable lifestyles and feeling unable to cope with responsibilities. P1 gave an account suggesting he was overwhelmed by his lifestyle:

"things were crazy, cos of, as I say, jobs (slight pause) bringing me down. Erm, (slight pause) the kids situation, I was still being pulled in three directions, and having to pay for this, pay for that, and then there was the music, and going to work (slight pause) drinking all day, getting one or two deals maybe. Then I'm going to the studio, and I'm there till about twelve. 
And then, I finally get back to the flat, really really late. And so I'm just out all day, and it's just a crazy way to live."

Many participants recalled chaos, such as serving numerous prison sentences, relocating frequently, and unstable employment. This lead to them feeling trapped due to a lack of opportunities. P5 was homeless and felt unable to develop stability; he directly attributes this to why he offended:

"What I was doing, how I was acting, you know my role in life. You know and nothing was happening, and you know I'm still in the same place, I'm still living the way l'm living. And I suppose all that came to a head. Erm and i kept thinking that, you know this has been going on for years and I'm still here. Err and then eventually I just said fuck it."

All participants described being trapped in situations that they lacked the skills or support to get out of. They indicated that they were unhappy with their lives around the time of offending. Their descriptions suggest they felt they had little to lose by offending, and even that going to prison would be a way out of their current situation.

\section{Superordinate theme 2: I'm not bad, I did what anyone would do.}

This represents how participants protected themselves from the negative feelings relating to their actions, typically utilising the mantra of 'if you had had my life, you would have ended up doing the same thing'.

Subordinate theme 2.1: I'm a nice person really. 
Participants had a tendency to highlight their positive or likeable behaviours and attributes, perhaps in an effort to not be defined by their offence. P1 did this in a lighthearted way, by bringing in his positive interests to undermine the negative behaviour: "now alongside my thuggary (laughs) I was very much into my dancing" He suggests there was a different side to him that became lost. This helps to support his view of being someone who took a wrong turn in life. He also described a softer image of sensitivity, innocence and initially willingness to show his vulnerabilities to women, describing his ex-girlfriend as 'reducing him to tears' and how he cried to her mother. Despite their difficulties and lack of relationship skills; participants presented themselves as initially willing to let people in and support them. P2 admits he struggled to communicate within relationships, but that he would offer support to his partner in the best way he knew how:

"I just let her you know, cry it out, and let her feel that she could (inaudible) I put my arms round her so she was comfortable, so she felt safe."

At times, participants attempted to highlight positive behaviours even when they were within the context of offending. Thus, P4 pointed out that after (accidentally) murdering his victim he did not take her money because he felt too guilty. P3 attempted to minimise the brutality in his behaviour while giving an accurate account of what happened:

"I didn't want to hurt her. Erm, because I'm not like that. Erm, but at the time,

I pulled this knife out. and I, errrr, dragged her onto the floor."

Participants were careful to define boundaries around what they did and did not do. P3 stated "I wasn't rough. I mean, I'm not a, a wild man or anything like that." This suggests his belief is that the offence could have been worse if it had been committed by someone else. 
Participants also talked about their own vulnerable emotions during offending, such as shock, guilt and panic. There appeared to be a desire to demonstrate that they are not cold hearted and have normal emotions that others can relate to. Participants also highlighted their own positive attributes by showing respect to their victim, often through compliments and expressions of regret.

\section{Subordinate theme 2.2: Anyone would have done what I did in the situation.}

Participants frequently attempted to justify or normalise their behaviour. Some implied that they did not have much choice and responded to the situation in the best way they could. P1 suggested that when faced with racist abuse he had two choices, "sink or swim". To swim meant to fight back and adapt to the environment, which he did by forming a gang and committing crime in the area in response to the negative beliefs he was developing about the world around him. P2 points out that his morals were "switched off" as a result of being a victim of sexual abuse and other negative experiences. Participants implied that their behaviour was down to circumstance, and that anyone would have done the same in that situation.

Other participants talked about their sexual behaviour as being what any man would have done. P3 expresses his opinion about men and sex, suggesting that his sexual behaviour is 'natural' and that all men are the same:

"I'm a man. A lot of people watch them (pornography). You ask half the lads in here. They've watched them. You know. Not all the time, no. I'd watch them now and again. You know, its life isn't it. It's a man's a predator. Not in the sense that he wants to hurt somebody. In a sexual way. You know. He'll want a girlfriend or something like that. He'll go out and get one. or try 
their best anyway. Sometimes it doesn't work (laughs slightly). But a man is a predator for sex isn't he?"

This serves to take away some of the responsibility for his sexual behaviour during his offence and in the lead up to it; other participants implied any man would become sexually aroused in the situations they were in. P4 stated:

"She'd put her hand on my legs, and from there then she'd say ah yeah, and she'd be further up my, then to the top of my thighs, and say yeah yeah. And erm, by then l'm obviously getting hard."

The use of the word obviously suggests that despite the age gap between himself and the victim, he became aroused, and that this was to be expected.

Subordinate theme 2.3: It wasn't 'me'...I wasn't in my right mind/l didn't know better.

Participants typically separated themselves from their behaviour in an effort to demonstrate that, for diverse reasons, they were not of sound mind when offending, perhaps because of alcohol, emotions, or because a different part of their personality had taken over. P2 removes personal responsibility for his behaviour by describing it as a "trigger response" and a "mechanical response" that he developed as a consequence of abuse. This "mechanical response" appears to indicate the removal of responsibility, but could also be a reflection the participant's trauma. He talks about having "two hearts", which suggests he feels that part of him did not what to commit the offence, but the other part lost control: 
"It's like two hearts, normal and not normal. The normal does not wanna get involved, just wants a peaceful life. The abnormal wants to stand up, shout and confront."

P3 talks about how drugs and alcohol affected his thinking and refers to his "old head" as fantasising, rather than him. By making this distinction, he is disassociating himself from his thoughts which he indicates were caused by drugs, suggesting that offending was not his intention.

"Me old head, started to fantasise about [the victim] and that. Because of my drugs and, thing I was taking. So, that started to enter my head. And so I used to think about. (Slight pause) I wonder what [the victim] is like in the nude."

This theme summarises how participants make sense of their actions, whilst protecting their view of themselves as not inherently bad. Conversely, while responsibility taking is ideal in order to benefit from treatment, preserving a positive self-image is important, as a negative self-image could present a barrier to change. Nevertheless, some beliefs about the offence and other people can increase the risk of reoffending if the individual continues to hold them (Maruna \& Mann, 2006).

\section{Superordinate theme 3: Other people haven't helped me or have made things} worse.

Participants described problematic relationships and placed blame on others suggesting for example, that the victim led them on, or that mothers, family, partners or authorities let them down. They expressed dissatisfaction in relationships, describing them as poor quality and lacking in communication, which meant they ended up existing in a relatively solitary world, despite having some relationships 
around them. Typically there was no one with whom they could discuss their thoughts and feelings.

\section{Subordinate theme 3.1: Mum/family haven't been there for me.}

All participants recalled negativity of some sort with family, mostly relating to their mothers. P1 referred to his mother throughout his account, often stating that she did not like him or disapproved of his actions and who he was becoming. However, his reference to his mother's views throughout the interview suggests her opinion was important to him. He talked about how he felt extremely let down when she did not offer him the support he wanted when his partner became pregnant:

"she said well if she trapped you then, well that's your own fault. And that just stunned me to be honest. I was like woah, so I'm your son;"

There is a sense of feeling shocked, let down, and eventually resentful because his expectations of support had not been met. P2 indicated that he felt let down that his parents did not find out about his abuse and prevent it. He felt if they had found out, he would not have carried the secret for a number of years and described them as "damn good at pushing things under the carpet". P5 recalled feeling that his family were not there for him, so he tried to be completely independent. As a result, he never attempted to seek emotional support and did not trust family:

"People that were close to me, I felt abandoned. Do you know what I mean? And even today, I say, friends are more, certainly more reliable than family. I said if anybody's gonna mess you up, it'd be family. and er, you know. So basically l'd had to sort of fight on my own. Battle, battle my way through, on my own." 
His use of strong words like 'battle' and 'fight' suggest that the world was an enemy, and life was a struggle. It indicates that he feels his family are partially responsible for the way he is. Generally participants indicated that they lost interest in developing relationships with their parents and that any later attempts of reconciliation were too little, too late.

\section{Subordinate theme 3.2: Partners/women have let me down or played me (including victims).}

Participants indicated that they felt the behaviour of women had contributed to their offending. They described the actions of a variety of women in their lives, indicating that they had led them on or 'played' them.

There was also a tendency for participants to suggest that victim behaviour was sexually provocative. P3 suggested his victim would "get him going, with different things". He also describes her actions during the offence as further inciting his behaviour. P4 describes the victim's sexual behaviour towards him prior to the offence, suggesting that she created a sexual environment. P5 explained that he had a casual sexual relationship with his victim previously, and that this had been easily obtainable:

"And she said do you want to come to my flat? Straight in her flat, without a thing, shagged her and that was it. Boom, job done, $i$ thought god, this is the easiest, I couldn't believe it. She couldn't get her kit off quick enough. I thought it's great, you know what I mean?"

It appeared that as a result he felt entitled to and expectant of sex with her in the future. $\mathrm{P} 1$ talks through three relationships where each partner became pregnant against his will. He felt the women were at fault and therefore were largely responsible for his situation. He was clear about how this impacted on his feelings towards women: 
"all this time my, my views on women are suffering, I'm not getting close to any women."

P4 describes feeling dissatisfied in his sexual relationship with his partner, and therefore more likely to accept the advances of his victim. He appears to divide blame between his victim for her sexual advancements, and his partner for her lack of sexual prowess. Other participants describe relationship problems such as partners attempting to control them or leaving them.

This theme demonstrates that the participants held negative and unhelpful views about women, relationships and sex, including beliefs that women are not supportive, they lie, let you down, and will lead you on sexually.

\section{Subordinate theme 3.3: Peers and the public have led me astray or not supported me.}

Participants described how friends, acquaintances and strangers impacted them in ways that made life more difficult, including negative reactions from other prisoners in custody, due to the nature of their offence. Participants generalised their beliefs from negative experiences to all people or all people within that group. P1 describes how the public did not buy a product he was selling at a time when he was struggling to cope. This left him generalising the negativity he felt towards these people, to all people:

"it felt like I was seeing, the weakness of humanity. At times. You know I was, I could, some time I could save people, you know, HUNdreds of pounds here, but they was like 'oh no, I'll just send British Gas out." He appears to take it personally making a grand inference about humanity. 
Most participants described how others got them involved in crime or some form of unhelpful behaviour. For example, P4 assaulted a bus driver because his friend told him to:

"he was telling us to join in, and then I joined in, I just joined in. I hit him, the bus driver, to let us off,"

The participant provides an impression of himself as an innocent, loyal friend being swept along by others. Therefore being let down by others, who abused his innocence

and desire to be liked. P4 talked about going to a doctor at a hospital where he worked for support with his worries about mortality. He felt the response he was given was unsupportive and made him feel worse:

"one of the doctors said, the older you get. (Slight pause) The more, you're gonna think about it. (Slight pause) and it's err, that's always stayed with me. Ever since he said that."

None of the participants described good quality relationships with pro-social peers or having anyone they could rely upon for support; they described being isolated and avoiding problems or attempting to address them alone.

\section{Subordinate theme 4.1: Authority and government have treated me badly and not helped me.}

This theme stems from participants' distrust of authority and was articulated via beliefs that prison staff lacked understanding or wiliness to help them, but also on a broader scale through lack of faith in the government.

P2 describes prison staff as putting their "own spin" on him, suggesting he did not trust them and felt they did not have his interests at heart. This demonstrates continued 
mistrust in others and a sense of feeling isolated, which was evident in all participants. P1 makes reference to "danger" and risk of "exposure" when discussing treatment programmes, indicating distrust of the system. Participants refer to other authorities that they feel have let them down. P3 describes losing his job due to depression, despite authorities giving him the job while aware of his depression. He shows awareness of the consequences of becoming unemployed and it appears that he holds the authorities responsible for his situation:

"They got rid of me because, I suffer from depression. Erm. I said they give me the job in the first place. I had to see two specialist doctors, before they gave me the job, and they give me the go ahead. So, I said now l've lost me job. I've got no money."

He attributes his unemployment, and having nothing to do, as a significant factor in his offending. Expectation and reliance on support and subsequent disappointment at not receiving it, was felt by all participants. P5 describes disappointment and anger towards the Government; he expresses this as a contributing factor to his offending: "At the time I was thinking I'm not proud to be English. Cos their kind of country like this, do what the countries doing to the people, you know to some people. So that's, that kind of made me angry a bit, that they mistreat. You know we're not exactly a poor country here. Erm. So, you know a lot of, a lot of that had to do with it as well."

Even though the participants describe being let down they continue to highlight helplessness and reliance on others, not knowing how else they can manage difficulties. The lack of positive relationships and support from others appears to have led to poor attachment and inadequate concern for people; to the point of wanting to "lash out" and "turn the tables" (P1). 


\section{Superordinate theme 4: Coping and pleasure.}

Alcohol and sex were commonly referred to as something to do for amusement or to manage emotions. The participants all described restricted lives, either due to their difficulty solving problems, and interacting with others, or because of actions attributed by others. With limited options, sex and alcohol were viewed as more obtainable than other possibilities, to pass time or as a way of coping with problems. Participants selfreported seeking impersonal sex, such as one night stands, due to inability to achieve intimate relationships. Participants also experienced financial restrictions due to lack of stable or well-paid employment, thus luxuries were unavailable and sex and alcohol were used in an attempt to fill the gap:

"if I'd had a bad day at work, then I would need sex and alcohol to recover from it, if I'd had a good day at work, l'd need sex and alcohol to celebrate it" (P1)

P1 later describes sex and alcohol as "everything" and going "hand in hand", demonstrating that he did not feel he had anything else readily available and was dependent on both. Sex and alcohol appeared to be a big factor in all participants' lives.

Subordinate theme 4.1: Sex can be with anyone, it's a physical release. Participants often engaged in impersonal sex and described it as something they needed in order to deal with their day to day lives or to release a build-up of emotions. P1 refers to sex as a "medication", while P2 reflected that he was having impersonal sex with and felt no intimate connection towards his sexual partners: 
"I was having these one night stands with girls and women, that, didn't mean nothing to me."

In this case, referring to some of his sexual partners as 'girls' appears to further demonstrate this participant's lack of connection with them. The majority of participants said that they were not attracted to their victims. P5 described his offending as a "frustration release" as he felt desperate for sex and found intimacy difficult to achieve, due to living on the streets. He chose his victim because he perceived her to be accessible.

As well as a way to cope and celebrate, sex would be a way to pass time and deal with boredom. P3 described how he watched pornography and began to have sexual thoughts about his victim after he lost his job:

"I used to watch porn films. Yeah. On video, Errr, DVD. I used to borrow from the shop. And I used to think to myself, I wonder what [victim] would look like in those black suspenders or, er, that black bra. Or which other women. I mean I tried to; I started to get in my head, because I didn't have sex with her."

Some participants described being unfaithful to partners and breaking boundaries of what is considered socially acceptable, not just during their offence. For example, one participant had sex with his father's wife, another with his girlfriend's mother. This suggests that sexual predilection did not merely cross social boundaries but indicated an intra-familial, older partner preference - a notion that would benefit from further research and analysis with this population. Thus, participants appeared to lack understanding of social boundaries that would inhibit this type of sexual activity with 
extended family members, and they also demonstrated a putative attraction to older sexual partners.

\section{Subordinate theme 4.2: Alcohol is something to do and a way to cope.}

Participants talked about using alcohol to try and escape from problems or emotions that they felt unable to manage. P2 had spent the entire day drinking prior to committing his offence. He suggests this had been an attempt to forget his feelings, which did not work:

“We went drinking from 11 o'clock [am] until 12 o'clock that night, and as, funnily enough, as much as I was drinking, I could not get drunk, I could not get blotto."

P3 talks about turning to alcohol due to limited options and goals in his life, providing a way to pass the time:

"I started drinking a lot heavier because I had nothing to do."

Alcohol appeared to be an important factor due to a lack of hobbies and interests and lack of finances, resources or awareness to do anything else. P4 talks about having an alcohol related hobby and drinking alone:

"I used to make home brew as well and I used to go out drinking myself" Lack of pro-social friendships potentially prevented the participants from being introduced to more positive pastimes.

\section{Discussion}

The study highlighted how individuals who sexually offend against elderly females make sense of their behaviour and identify factors that they see as contributing to their offending. Accounts focus on the impact of external factors that lead them to develop unfulfilling lives with few skills to address their predicament. The accounts play down 
the role of personal choice and agency. The role of sexual desire in their offending is also dismissed, or at least justified. Participants were open to acknowledge the wrongdoing in their behaviour and a need to change, whilst protecting the self as not fully responsible.

Muram et al. (1992) and Cartwright and Moore (1989) identified availability and vulnerability as key factors in offences against elderly victims in general. The study provides support for these commonalities found in the research in that all the victims lived alone and were attacked in their own home. Additionally, all participants had a criminal history prior to offending, echoing the findings of Lea et al's (2011) mixed method research. Participants also described regular alcohol use and claimed to be under the influence of alcohol at the time of offending, a similar finding to Collins and Connor (2000), who asserted alcohol dependence as the one of the most common features among offences against elderly victims.

All participants in the current study described difficulties with life adjustment in early adolescence and some of or all of the following: a lack of respect or resentment towards their mothers, unstable parental relationship and/or feeling of rejection. This supports the findings of Groth's (1978) research into men who offend against victims who were significantly older than themselves.

In support of Groth's (1978) sexual offender typologies, this study provides evidence of both anger rape and power rape. The two were generally found to be interlinked in the current study as participants felt a lack of control in their lives. This resulted in feelings of anger and a desire to achieve feelings of power to compensate for their 
lack of control. As a result, participants reported they experienced a build-up of anger, with their offence being an expression of that anger and an attempt to (re)gain some power. While the majority of participants in this study $(n=5)$ used a high degree of brutality in their offence, they did not describe sadistic intent, despite their offences involving significant violence. However, this is unsurprising given that the current study used IPA and participants are perhaps unlikely to choose to discuss sadistic behaviour. Groth's findings do not clearly account for opportunistic behaviour and a goal of sexual gratification, both of which were found to be present in this study.

The current findings appear reminiscent of Prentky and Knight's (1991) findings that offences against elderly victims were often opportunistic, and/or related to pervasive anger, a desire for sexual gratification and vindictiveness. Similar to Prentky and Knights findings, participants reported that they were generally driven by anger, which developed as a result of feeling they had a tough life and a lack of support from others. They used sex to pass the time and to cope, and sexual gratification and poor sexual boundaries were also factors in offending. Participants primarily described their offending as opportunistic, and based on victim accessibility, rather than sexual attraction. However, this could be a rationalisation, as it is a more socially acceptable explanation than admitting to sexual attraction to their elderly victims. The themes identified in the current study are arguably similar to the implicit theories that have been found in research into cognitive distortions held by rapists, such as 'dangerous world', 'women are unknowable or dangerous' and 'sex drive is uncontrollable' (see Polaschek \& Ward, 2002; Polaschek \& Gannon, 2004; Beech, Ward \& Fisher, 2006, Ward 2000). 
It is important to note, as highlighted by Maruna and Mann 2010, that offenders should not be pathologised for using these various explanations for their actions. When asked to explain our behaviour it is common for people to use variety of justifications, particularly if actions are not socially desirable, in order to distance ourselves from a negative behaviour. However, it is important to identify and address the cognitive distortions (or offence supportive beliefs) that are entrenched and which may facilitate a repeat of the behaviour.

Findings indicate that participants were highly sexually preoccupied at the time of their offences and were using sex as a physical release to cope. They felt they lacked of control of their lives due to other people's influence on them such as their mothers or partners. They also referred to issues with their childhood affecting them in later life. The participants experienced anger as a result of this and targeted their victims due to their perceived vulnerability and/or accessibility. While the victim themselves may or may not be the offender's sexual preference, the sexual act, the release of anger and sense of power achieved as well as accessibility are of greater importance to the offender. This study provides little evidence for a specific sexual preference for elderly people (gerontophilia; Kaul \& Duffy, 1991); however, some participants reported engaging sexual contact with people who are of an older generation, outside of their offending. The lack of evidence for Gerontrophilia could be a consequence of the form of analysis used. Participants are given freedom to describe their offending in their own words. Therefore they are perhaps unlikely to describe themselves as having a sexual interest that is not considered to be socially desirable or acceptable. 
The findings of this study fit with the treatment areas that UK Prison and Probation Services currently aim to address when working with sex offenders (SARN TNA; Thornton, 2002). This includes impulsivity and instability, poor problem solving, and lack of intimacy. Some offence supportive beliefs that seemed apparent in the current research are also accounted for in current treatment of sex offenders, such as sexual entitlement and mistrust of women. The SARN TNA also has the flexibility to account for the sexual interests in this study. It is of note however that some of the beliefs about women and sex relayed by participants echo unhelpful beliefs that are held in general society and at times are further reinforced by media, indicating that there is more that society can do to challenge these beliefs and to prevent young adults from developing them.

It is important to be mindful of the limitations of this study when considering the utility of the findings. It is not possible to generalise the findings to all rapes against elderly females. However, this research presents a rich understanding of five adult males who have committed offences of this nature. Commonalities from this research provide a basis for future research into this group of offenders. It should also be acknowledged that only $20 \%$ of the potential participants agreed to take part. While this response rate is higher than typically found in social sciences research, it is likely to contain bias in terms of those who volunteered.

Given that participants are in custody, some serving indeterminate sentences, it is likely that they will want to appear reformed. There could have been more sadistic/vindictive intent within their offences, or further details that participants felt were not in their interests to disclose. Furthermore, when asked what Offending 
Behaviour Programmes they had completed, two participants stated that they had completed treatment designed for a lower level of intellectual functioning. Therefore intellectual abilities could have impacted on their ability to express themselves.

Further research on this group of offenders is indicated by the current study. Quantitative research focusing on these individuals who offend against the elderly would allow clinicians to unravel putatively complex interactions between disparate criminogenic needs and background factors (such as alcohol abuse and lack of stable authority figure in childhood). The potential importance of this is reflected in the findings from this research that present a group that commits offences that are both severe (all were rape) and predominantly violent in nature (4/5). Understanding why this was so might be the focus of a further qualitative or mixed method research study in order to help protect elderly people from such appalling acts.

\section{Conclusion}

The aim of the current research was to develop insight into the perspectives of men who sexually offend against elderly victims. Participants felt their negative experiences in life had shaped them, and that their offending was effectively a result of this. In viewing their offending from this perspective, they were able to view themselves as inherently good. Participants also blamed others, particularly mothers, but also other family members, friends, partners and authority figures for letting them down or not being supportive toward them. A putative attraction to older partners was demonstrated in participants' talk, but was downplayed in their own explanations of their choice of victims, which focused on participants' negative life experiences, and the need both to cope with challenges and also to derive pleasure in their lives. 
Table 1 - Demographic and Offence Data of Participants

\begin{tabular}{|c|c|c|c|c|c|c|c|}
\hline $\begin{array}{l}\text { Participant } \\
\text { number }\end{array}$ & $\begin{array}{l}\text { Offender } \\
\text { age at time } \\
\text { of the } \\
\text { offence }\end{array}$ & $\begin{array}{l}\text { Age of } \\
\text { victim }\end{array}$ & $\begin{array}{l}\text { Offender } \\
\text { relationship } \\
\text { to victim }\end{array}$ & $\begin{array}{l}\text { Observed } \\
\text { ethnicity of } \\
\text { offender }\end{array}$ & Offence & $\begin{array}{l}\text { Living situation } \\
\text { of victim }\end{array}$ & $\begin{array}{l}\text { Location of } \\
\text { offence }\end{array}$ \\
\hline P1 & 31 & 56 & Stranger & Black British & Rape & Lived alone & $\begin{array}{l}\text { Victims } \\
\text { home }\end{array}$ \\
\hline P2 & 23 & 70 & Nephew & White British & $\begin{array}{c}\text { Rape and } \\
\text { murder }\end{array}$ & Lived alone & $\begin{array}{l}\text { Victims } \\
\text { home }\end{array}$ \\
\hline P3 & 46 & 67 & $\begin{array}{l}\text { ex-partner } \\
\text { (casual) }\end{array}$ & White British & Rape & Lived alone & $\begin{array}{l}\text { Victims } \\
\text { home }\end{array}$ \\
\hline P4 & 20 & 67 & $\begin{array}{c}\text { Acquaintance, } \\
\text { casual sexual } \\
\text { partner }\end{array}$ & White British & $\begin{array}{c}\text { Rape and } \\
\text { murder }\end{array}$ & Lived alone & $\begin{array}{l}\text { Victims } \\
\text { home }\end{array}$ \\
\hline P5 & $33 / 40^{*}$ & $55 / 60^{*}$ & $\begin{array}{l}\text { Acquaintance, } \\
\text { previous } \\
\text { causal sexual } \\
\text { partner. }\end{array}$ & White British & $\begin{array}{l}\text { Rape (two } \\
\text { victims) }\end{array}$ & Lived alone & $\begin{array}{l}\text { Victims } \\
\text { home }\end{array}$ \\
\hline
\end{tabular}

${ }^{\star}$ Ages were estimated by participant 
Table 2 - Summary of Themes

\begin{tabular}{|c|c|c|c|c|}
\hline & Theme 1 & Theme 2 & Theme 3 & Theme 4 \\
\hline $\begin{array}{l}\text { Primary } \\
\text { Theme }\end{array}$ & $\begin{array}{l}\text { Life's been } \\
\text { really tough. }\end{array}$ & $\begin{array}{l}\text { I'm not bad, I } \\
\text { did what } \\
\text { anyone would } \\
\text { do. }\end{array}$ & $\begin{array}{l}\text { Other people } \\
\text { haven't helped } \\
\text { or have made } \\
\text { things worse. }\end{array}$ & $\begin{array}{l}\text { Coping and } \\
\text { pleasure. }\end{array}$ \\
\hline $\begin{array}{l}\text { Sub } \\
\text { Themes }\end{array}$ & $\begin{array}{l}\text { I didn't get a } \\
\text { good start in } \\
\text { life } \\
\text { (childhood). } \\
\text { Bad things } \\
\text { have } \\
\text { happened to } \\
\text { me } \\
\text { (adulthood). } \\
\text { My life's not } \\
\text { been what I } \\
\text { wanted it to be. }\end{array}$ & $\begin{array}{l}\text { I'm a nice } \\
\text { person really. } \\
\text { Anyone would } \\
\text { have done } \\
\text { what I did in } \\
\text { the situation. } \\
\text { It wasn't } \\
\text { 'me'...I wasn't } \\
\text { in my right } \\
\text { mind/l didn't } \\
\text { know better. }\end{array}$ & $\begin{array}{l}\text { Mum/family } \\
\text { haven't been } \\
\text { there for me. } \\
\text { Partners/women } \\
\text { have let me } \\
\text { down or played } \\
\text { me (including, } \\
\text { victims). } \\
\text { Peers and the } \\
\text { public have led } \\
\text { me astray or not } \\
\text { supported me. } \\
\text { Authority and } \\
\text { government } \\
\text { have treated me } \\
\text { badly and not } \\
\text { helped me. }\end{array}$ & $\begin{array}{l}\text { Alcohol is } \\
\text { something to } \\
\text { do and a way } \\
\text { to cope. } \\
\text { Sex can be } \\
\text { with anyone. } \\
\text { It's a physical } \\
\text { release. }\end{array}$ \\
\hline
\end{tabular}




\section{References}

Acierno, R., Hernandez, M. A., Amstadter, A. B., Resnick, H. S., Steve, K., Muzzy, W., \& Kilpatrick, D. G. (2010). Prevalence and correlates of emotional, physical, sexual, and financial abuse and potential neglect in the United States: The National Elder Mistreatment Study. American journal of public health, 100(2), 292-297. Amir, M. (1971). Patterns in forcible rape (p. 52). Chicago: University of Chicago Press.

Bonta, J., \& Andrews, D. A. (2007). Risk-need-responsivity model for offender assessment and rehabilitation. Rehabilitation, 6, 1-22.

American Psychiatric Association. (2013). Diagnostic and statistical manual of mental disorders (DSM-5®). American Psychiatric Pub.

Babchishin, K. M., Nunes, K., \& Kessous, N. A. (2013) Multimodal examination of sexual interest in children: a comparison of sex offenders and non sex offenders. Sex Abuse; 26:343-374.

Ball, H., Snowden, P., \& Strickland, I. (1992). Sexual offences on older women: Psychopathology of the perpetrator. The Journal of Forensic Psychiatry, 3(1), 160166.

Ball, H. N. (2005). Sexual offending on elderly women: A review. Journal of Forensic Psychiatry \& Psychology, 16(1), 127-138.

Beech, A., Friendship, C., Erikson, M., \& Hanson, R. K. (2002). The relationship between static and dynamic risk factors and reconviction in a sample of UK child abusers. Sexual Abuse: A journal of research and treatment, 14(2), 155-167.

Beech, A. R., Ward, T., \& Fisher, D. (2006). The identification of sexual and violent motivations in men who assault women: Implication for treatment. Journal of Interpersonal Violence, 21(12), 1635-1653. 
Bumby, K. M. (1996). Assessing the cognitive distortions of child molesters and rapists: Development and validation of the MOLEST and RAPE scales. Sexual Abuse: A Journal of Research and Treatment, 8(1), 37-54.

Burgess, A. W., \& Morgenbesser, L. I. (2005). Sexual violence and seniors. Brief treatment and crisis intervention, 5(2), 193.

Burgess, A. W., Commons, M. L., Safarik, M. E., Looper, R. R., \& Ross, S. N. (2007). Sex offenders of the elderly: Classification by motive, typology, and predictors of severity of crime. Aggression and Violent Behavior, 12(5), 582-597.

Cartwright, P. S., \& Moore, R. A. (1989). The elderly victim of rape. South. Med. J. $82(8): 988-9$

Ciardha, C. Ó. (2011). A theoretical framework for understanding deviant sexual interest and cognitive distortions as overlapping constructs contributing to sexual offending against children. Aggression and Violent Behavior, 16(6), 493-502.

Collins, P. G., \& O'Connor, A. (2000). Rape and sexual assault of the elderly-an exploratory study of 10 cases referred to the Irish Forensic Psychiatry Service. Irish Journal of Psychological Medicine, 17(04), 128-131.

Fletcher, P. (1977). Criminal victimization of elderly women: A look at sexual assault. Syracuse, NY: Rape Crisis Center of Syracuse.

Gannon, T. A., Collie, R. M., Ward, T., \& Thakker, J. (2008). Rape:

Psychopathology, theory and treatment. Clinical psychology review, 28(6), 9821008.

Gannon, T. A., \& O'Connor, A. (2011). The development of the interest in child molestation scale. Sexual abuse: a journal of research and treatment, 23(4), 474493. 
Greenfield, L. A. (1997). Sex offenses and offenders: an analysis of data on rape and sexual assault: sex offenses and offenders (Washington, DC, US Department of Justice).

Groth, A. N. (1979). Men who rape: The psychology of the offender. Plenum Press. New York.

Groth, A. N., \& Birnbaum, H. J. (2013). Men who rape: The psychology of the offender. Springer.

Help the Aged (2006) Crime and fear of crime. Retrieved from

http://www.ageuk.org.uk/documents/en-gb/for-professionals/communities-andinclusion/crime_and_fear_of_crime_2006_pro.pdf Hicks, D. J. (1977). Rape: sexual assault. Obstetrics and gynecology annual, 7, 447-465.

Holt, M. G. (1993). Elder Sexual Abuse in Britian: Preliminary Findings. Journal of Elder Abuse \& Neglect, 5(2), 63-71.

Janssen, D. F. (2014). "Gerontophilia": A Forensic Archaism. Sexual Offender Treatment, 9(1).

Jefferson, G. (2004). Glossary of transcript symbols with an introduction. Pragmatics and Beyond New Series, 125, 13-34.

Jewkes, R., Sikweyiya, Y., Morrell, R., \& Dunkle, K. (2014). Why, when and how men rape: Understanding rape perpetration in South Africa. South African Crime Quarterly, 34, 23-31.

Krafft-Ebing, R. V. (1886). Aberrations of sexual life, the psychopathia sexualis, 1959 ed.

Kaul, A., \& Duffy, S. (1991). Gerontophilia-a case report. Medicine, Science and the Law, 31(2), 110-114. 
Klaus, P. A. (2000). Crimes against persons age 65 or older, 1992-97. Bureau of Justice Statistics.

Klaus, P. A. (2005). Crimes against persons age 65 or older, 1993-2002. US Department of Justice, Office of Justice Programs, Bureau of Justice Statistics. Lanning, K. V. (1994). Child molesters: a behavioural analysis. School Safety, $12-$ 17.

Lea, S. J., Lanvers, U., \& Shaw, S. (2003). Attrition in rape cases. Developing a profile and identifying relevant factors. British Journal of Criminology, 43(3), 583599.

Langton, C. M., \& Marshall, W. L. (2001). Cognition in rapists Theoretical patterns by typological breakdown. Aggression and Violent Behavior, 6(5), 499-518.

Lievesley, R., Elliott, H. J., Winder, B., \& Norman, C. (2014). Understanding service users' and therapists' experiences of pharmacological treatment for sexual preoccupation and/or hypersexuality in incarcerated sex offenders. The Journal of Forensic Psychiatry \& Psychology, 25(3), 262-287.

Macdonald, J. M. (1971). Rape offenders and their victims. Springfield, IL: Thomas. Manthorpe, J., Biggs, S., McCreadie, C., Tinker, A., Hills, A., O’Keefe, M. \& Erens, B. (2007). The UK national study of abuse and neglect among older people. Nursing older people, 19(8), 24-26.

Maruna, S., \& Mann, R. E. (2006). A fundamental attribution error? Rethinking cognitive distortions†. Legal and Criminological Psychology, 11(2), 155-177.

McPhail, I. V., Hermann, C. A., \& Nunes, K. L. (2013). Emotional congruence with children and sexual offending against children: A meta-analytic review. Journal of consulting and clinical psychology, 81(4), 737. 
Muram, D., Miller, K., \& Cutler, A. (1992). Sexual assault of the elderly victim. Journal of Interpersonal Violence, 7(1), 70-76.

Prentky, R. A., \& Knight, R. A. (1991). Identifying critical dimensions for discriminating among rapists. Journal of consulting and clinical psychology, 59(5), 643.

Polaschek, D. L., \& Gannon, T. A. (2004). The implicit theories of rapists: What convicted offenders tell us. Sexual Abuse: A Journal of Research and Treatment, 16(4), 299-314.

Pollock, N. L. (1988). Sexual assault of older women. Annals of sex research, 1(4), 523-532.

Reid, K., Flowers, P., \& Larkin, M. (2005). Exploring lived experience. Psychologist, 18(1), 20-23.

Safarik, M. E., Jarvis, J. P., \& Nussbaum, K. E. (2002). Sexual homicide of elderly females linking offender characteristics to victim and crime scene attributes. Journal of Interpersonal Violence, 17(5), 500-525.

Scharf, T., Phillipson, C., Smith, A. E., \& Help the Aged, London (United Kingdom);. (2002). Growing older in socially deprived areas Social exclusion in later life.

Sigre-Leirós, V., Carvalho, J., \& Nobre, P. (2015). Cognitive schemas and sexual offending: Differences between rapists, pedophilic and nonpedophilic child molesters, and nonsexual offenders. Child abuse \& neglect, 40, 81-92.

Smith, J. A., Harré, R., \& Van Langenhove, L. (Eds.). (1995). Rethinking methods in psychology. Sage.

Smith, J. A. (Ed.). (2007). Qualitative psychology: A practical guide to research methods. Sage. 
Thornton, D. (2002). Constructing and testing a framework for dynamic risk assessment. Sexual Abuse: A Journal of Research and Treatment, 14(2), 139153.

Twigg, J. (2004). The body, gender, and age: Feminist insights in social gerontology. Journal of aging studies, 18(1), 59-73.

Tyra, P. A. (1996). Helping elderly women survive rape using a crisis framework. Journal of psychosocial nursing and mental health services, 34(12), 20-25.

Walby, S., Allen, J., \& Simmons, J. (2004). Domestic violence, sexual assault and stalking: Findings from the British Crime Survey. London: Home Office Research, Development and Statistics Directorate.

Waldram, J. B. (2007). Everybody has a story: Listening to imprisoned sexual offenders. Qualitative Health Research, 17(7), 963-970.

Winder, B., \& Gough, B. (2010). "I never touched anybody—that's my defence": A qualitative analysis of internet sex offender accounts. Journal of Sexual Aggression, 16(2), 125-141.

Ward, T. (2000). Sexual offenders' cognitive distortions as implicit theories. Aggression and Violent Behavior, 5(5), 491-507. 